УДК 398.541

\title{
ОБРАЗ ПРОРОКА ИЛИИ \\ В БЕЛОРУССКОМ ФОЛЬКЛОРЕ
}

Патошина Анастасия Юрьевна

к.п.н., доцент

ФБГОУ ВО «Российская академия музыки им. Гнесиных»

(РАМ им. Гнесиных)

\begin{abstract}
Аннотация: Статья посвящена исследованию представлений об Илии пророке, сложившихся в традиционной культуре белорусского народа. Автор проследил историю проникновения культа пророка Илии из Византии в древнерусские княжества и трансформацию восприятия образа этого ветхозаветного персонажа в сознании белорусских крестьян. Материалом для изучения послужили тексты календарных песен, заговоров, народных молитв, легенд и поверий, связанных с именем пророка Илии.

Ключевые слова: Пророк Илия, народное христианство, традиционная культура, белорусский фольклор.
\end{abstract}

\section{THE IMAGE OF THE PROPHET ELIJAH IN BELARUSIAN FOLKLORE}

\section{Patoshina Anastasiya Y urievna}

\begin{abstract}
The article is devoted to the study of the ideas about Elijah the Prophet that have developed in the traditional culture of the Belarusian people. The author traces the history of the penetration of the cult of the Prophet Elijah from Byzantium into the Old Russian principalities and the transformation of the perception of the image of this Old Testament character in the minds of Belarusian peasants. The texts of calendar songs, conspiracies, folk prayers, legends and beliefs associated with the name of the prophet Elijah served as the material for the study.

Key words: Prophet Elijah, folk Christianity, traditional culture, Belarusian folklore.
\end{abstract}


Одним из библейских персонажей, который издавна почитается на белорусских землях, является святой пророк Илия, память которого православная церковь отмечает 20 июля/2 августа. Его жизнеописание изложено в третьей и четвертой «Книгах Царств» Ветхого Завета (3 Цар 17. 119; 18; 21. 17-28; 4 Цар 1. 3-17; 2. 1-18). По церковному преданию за свое служение пророк Илия заслужил особую милость Господа и живым был взят на небо. В тексте Нового Завета пророк Илия вместе с Моисеем присутствует на горе Фавор и беседует с Христом во время Его Преображения (Мк 9. 2-7; Мф 17. 3-5; Лк 9. 30-31).

После утверждения на территории Византийской империи христианства как государственной религии образ ветхозаветного пророка Илии в сознании новообращенных народов начал обретать сходство с чертами языческих богов. В тексте Ветхого Завета написано, что по молитве к Господу пророк Илия ниспослал дождь после гибельной засухи. Благодаря этому эпизоду из жизнеописания пророка в сознании носителей народной культуры его образ стал ассоциироваться богом-громовержцем и подателем дождя Зевсом. Вознесение святого Илии в огненной колеснице напоминало о колесницах бога солнца Гелиоса и бога света Аполлона.

В греческом фольклоре пророк Илия стал противником ламий мифических чудовищ-вампиров в образе полуженщин-полузмей. Мотив борьбы Илии с пресмыкающимися животными и нечистыми духами позже станет очень распространенным в народном христианстве у восточных славян, в частности, у белорусов. В то же время, непосредственного влияния греческих фольклорных мотивов на славянские представления о святом пророке Илии, скорее всего, не было: «У нас нет оснований предполагать, что... между Русью и Византией существовали регулярные связи на низовом уровне, следовательно, греческое «двоеверие» никак не могло повлиять на «двоеверие» русское», - писал историк средневековой культуры С. А. Иванов [3, с. 12].

В то же время нельзя не признать, что культ святого пророка Илии, расцвет которого в Византии пришелся на вторую половину IX столетия, вместе с христианизацией был перенесен и на территории проживания восточных славян. Вероятно, не случайно первый храм, возведенный греческими архитекторами в Киеве еще до официального принятия христианства в Древней Руси, был освящен в честь святого пророка Илии [3].

Представления о пророке Илии, сложившиеся в белорусской народной культуре, включали в себя как знания, почерпнутые литературных источников, 
так и многочисленные верования, основанные на переосмыслении образа этого ветхозаветного персонажа. Помимо признанных церковью канонических текстов из Ветхого и Нового Заветов, жития и акафиста на территории нынешних белорусских земель в эпоху средневековья циркулировали и апокрифические сочинения, связанные с именем пророка Илии. Это апокрифы «Ильино Обавление» и «Видение апостола Павла», в которых описывается пребывание пророка в раю, а также многочисленные списки «Похвалы пророку Илье», воспевающие его огненное восхождение на небеса [9].

В середине XIX столетия выдающийся исследователь славянского фольклора А. Н. Афанасьев пришел к выводу о том, что библейский образ пророка Илии в сознании носителей традиционной белорусской культуры приобрел черты языческого бога войны и громовержца Перуна. «По белорусскому преданию... Перун разъезжает по небу в огненной колесница и бросает с огненного лука стрелы молнии: атрибуты эти в позднейшую эпоху были перенесены на Илью-пророка» [1, с. 628]. По представлениям белорусских крестьян гром производят колеса золотой колесницы Илии, а молнии сыплются с неба от ударов копыт запряженных в нее коней.

В белорусском фольклоре пророк Илия предстает как один из духовпокровителей, обеспечивающий материальное благополучие земледельцев. В период зимних святок крестьяне пели песни-благопожелания, в которых одним из главных героев является пророк Илия. Так, по сюжету одной из колядок, на вопрос святого Петра, где он был, пророк отвечает:

«Я по полю пахадиў,

Жыта парадиў, святый вечер!

Жыта, пшаницы....

Па кашарах пахадиў,

Скот парадиў, святый вечер!» [7, с. 114]

В других текстах подчеркивается, что там, где святой Илия не прошел, ни жито, ни пшеница не вырастут. Пение колядок сопровождалось обсыпанием изб зернами с целью «повышения урожая» на предстоящий год. В текстах весенних волочёбных песен святой Илия выходит работать в поле вместе с крестьянами. После окончания сева между ним и Господом происходит совершенно «земной» диалог:

«Прышоў Ильля с цыстыга поля,

Увалацыўшысь и умацыўшысь. 
А сеў Ильля на бажницы,

А и стаў Гаспоть рыспрашывать:

- Какаво, Ильля, жыта наша?

-Слава Богу, наша жыта:

Колысым калосить, ядром ядренить» [7, с. 175]

В ночь на Ивана Купалу, которая по народным представлениям считалась временем бесчинства ведьм, святой Илия сторожит жито, чтобы ведьмы не сделали «заломов» в поле и не отняли у коров молоко. В белорусском фольклоре пророк Илия предстает как покровитель плодородия земли и домашних животных. В фольклорных текстах белорусских песен и легенд он ходит по земле, трудится в поле и помогает излечиться от болезней. Обращение к нему встречается в белорусских заговорах от испуга, от клопов и блох, от пожара (тот, кто может вызвать небесный огонь, может укротить и земной), от эпилепсии, сглаза («уроков») и укусов змей. В народных молитвах пророка называют «надзеляющим» и просят о даровании земных и духовных благ:

«А святый Ильля надзеляющий,

А здзеляй у доми хлебом-сольлю,

А ўсякею божай благодатьцю» [6, с. 418]

По белорусским поверьям пророк Илия во время грозы гонится за нечистыми духами и поражает их молниями. Черти, стараясь избежать гибели, вселяются в различных живых существ или пытаются проникнуть в дома. Поэтому во время грозы крестьяне выгоняли на улицу всех животных черного цвета, закрывали окна и печные заслонки, чтобы черт не мог пролезть в помещение. «Чтобы гром не поразил человека, необходимо во время ударов молнии креститься. Объясняется это тем, что дьявол, поражаемый Илиею, прячется от него, где только можно, в том числе и в человека, если он не кладет на себя крестного знамения» [7, с. 273].

В то же время человек, убитый молнией, считался угодным Богу, и, по убеждению крестьян, его душа сразу отправлялась в рай: «Если гроза чоловика убьет, то гэто святая смерть. Это значит, что он весь свой грех оддаў» [5, с. 137]. В Полесье о погибшем говорили: «Илья взял его к себе» [4, с. 267].

Гроза в народных представлениях была не только битвой Илии с нечистыми духами, но и воспринималась как спор самого Бога и черта. Таким образом, мотив борьбы пророка Илии с дьяволом сближает его фольклоризированный образ не только с языческим Перуном, но и с 
ветхозаветным Богом-Отцом. [9]. Крестьяне не тушили пожары, которые возникали от удара грома, так как считали, что это несчастье произошло по воле Бога и является частью великой битвы небесных сил и их антагонистов.

Белорусы относились к пророку с большой долей страха и говорили: «Съвяты Ильля вельмі сердзіты сьвяток» [3, с. 165]. Считалось, что пророк Илия жестоко наказывает людей, которые осмелились нарушить предписания, связанные в церковной традиции с днем его памяти. Например, 2 августа категорически запрещалось работать, прятаться под деревьями во время грозы и купаться после Ильина дня. В связи с этим интересна легенда об истории возникновения Ильинского храма в города Кричеве Могилевской области, в котором находится одна из самых известных белорусских икон пророка Илии, держащего в правой руке меч как символ борьбы с отступниками от веры в истинного Бога (рис. 1)

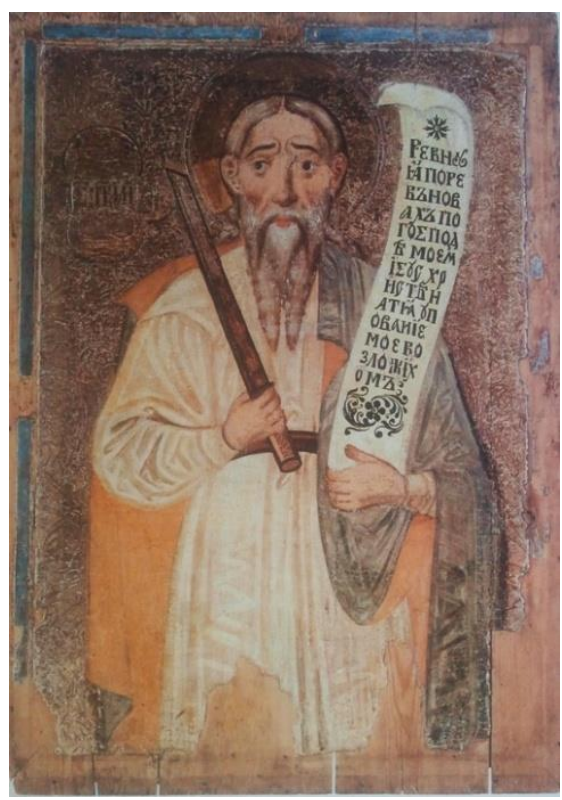

Рис. 1. Илья, 1668 год. Национальный художественный музей Республики Беларусь

Этот храм был выстроен на средства Великого князя литовского и короля польского Казимира IV в память о спасении его жены, едва не утонувшей в день памяти Илии пророка и вытащенной из воды простым рыбаком [8].

Народное почитание пророка Илии на белорусских землях сохраняется и в наши дни. В середине XX столетия в Жлобинском районе Гомельской 
области возникла легенда о чудесном явлении иконы пророка Илии в ветвях березы, росшей рядом с разрушенным большевиками храмом, и о целебной воде родника, протекавшего рядом с ним. И сейчас в день памяти Илии пророка жители соседних деревень приезжают на место, где стояла церковь, поклониться святому и поучаствовать в молебне в его честь [10]. В настоящее время на территории Республики Беларусь находится около 40 действующих храмов и часовен, освященных в честь пророка Илии. Каждый год 2 августа в них проводятся службы, посвященные памяти святого, крестные ходы и освящение воды.

Противоречивые представления о пророке Илии, помогающего людям или жестоко карающего их за нарушения запретов, сложившиеся на протяжении многих веков в традиционной культуре белорусского народа, основываются на нескольких разновременных источниках. Фольклоризированный образ Илии-пророка включает в себя отголоски языческого культа бога-громовержца и подателя дождя Перуна, знания, полученные из церковных канонических и апокрифических литературных источников, а также его народное восприятие в роли помощника и покровителя крестьянских трудов.

\section{Список литературы}

1. Афанасьев А. Н. Поэтические воззрения славян на природу: в 3 т. М.: Индрик, 1994. Т. 1. - 800 с.

2. Иванов В. В., Топоров В. Н. Исследования в области славянских древностей. Лексические и фразеологические вопросы реконструкции текстов. М.: Наука, 1974. - 342 с.

3. Иванов С.А. Когда в Киеве появился первый христианский храм? // Славяне и их соседи. Славянский мир между Римом и Константинополем. Выпуск 11. - М.: Индрик, 2004. с. 9-18.

4. Киркор А. К. Живописная Россия. Т. 3. Ч. 1: Литовское Полесье. Ч. 2. Белорусское Полесье. СПб.- М.: издание М. О. Вольфа, 1882. - 490 с.

5. «Народная Библия»: Восточнославянские этиологические легенды. М.: «Индрик», 2004. - $576 \mathrm{c.}$

6. Романов Е. Р. Белорусский сборник. Вып. 5. Заговоры, апокрифы и духовные стихи. - Витебск, Типо-Литография Г. А. Малкина, 1891. - 466 с. 
7. Романов Е. Р. Белорусский сборник. Вып. 8. Быт белоруса. - Вильна, типография А. Г. Сыркина, 1912. - 730 с.

8. Религиозные течения в жизни Кричевщины: история и современность. Информационно-краеведческий сборник. Кричев: Кричевская районная центральная библиотека, 2019. - 29 с.

9. Словарь книжников и книжности Древней Руси. Вып. 2 (вторая половина XIV- XVI в.) / Часть 1. А-К. / Отв. ред. Д. С. Лихачев. - Л.: Наука, 1988. - 516 с. // Сайт «Православный портал «Азбука веры»» [Электронный pecypc]. URL: https://azbyka.ru/otechnik/bibliog/slovar-knizhnikov-i-knizhnostidrevnej-rusi/43 (дата обращения: 11 октября 2021 года)

10. Шуканов Н. «2 августа Православная церковь чтит память пророка Илии» // «Новы дзень». Жлобинская районная газета. 02.08.2019 